\title{
The Current State of Forensics: A "Newbies" Perspective
}

\section{Dante Webb*}

Forensic Scientist I, Utah Bureau of Forensic Services, USA

*Corresponding author: Dante Webb, Forensic Scientist I, Utah Bureau of Forensic Services, 4501 South 2700 West, USA, Tel: 801-965-3870; E-mail: dwebb@utah.gov

Rec date: September 11, 2015 Acc date: September 15, 2015 Pub date: September 22, 2015

Copyright: $\odot 2015$ Webb D. This is an open-access article distributed under the terms of the Creative Commons Attribution License, which permits unrestricted use, distribution, and reproduction in any medium, provided the original author and source are credited.

\section{Opinion}

Ever since I was 12 years old it was my dream to be a forensic scientist. Like many others, my initial interested stemmed from the show "CSI" (the Las Vegas one). I would run to the TV every time I heard The Who's "Who Are You" opening theme and would watch as Grissom, Warrick and the rest of the original gang would dust for prints, look through microscopes and use alternate light sources (without any googles I might add) to help solve crimes, using science! I was hooked. As a kid I always liked mysteries (shout out to the Boxcar Children) and had an aptitude for science. Throughout high school I did fairly well in my science classes and my interest in forensics intensified. I chose California State University, at Los Angeles to start my forensic journey which had just built the Hertzberg Davis Forensic Science Center which housed the Los Angeles Police Departments' Criminalistics Laboratory (probably one of the largest in the United States), Los Angeles County Sherriff's Scientific Services Bureau, The California Criminalistics Institute and the California State University Los Angeles School of Criminal Justice and Criminalistics. For a kid growing up in Los Angeles, wanting to do forensics there was not a better place to go to school.

After years of hard work, schooling and interning (at LAPD, unsurprisingly) I was able to get hired at a U.S accredited State Crime Lab. Ecstatic to have finally been hired after a few rejections, and eager to learn everything I could about the field of forensic science my research led me to a number of articles attacking the field I was most passionate about. These articles would say things like there's "A disaster going on in today's crime labs" and "can we trust crime forensics?" My initial reaction was defensive. But I then re-read the articles and took another look at the National Science and Technology Councils report on strengthening the forensic sciences and began to realize that there is SOME merit to what is being said.

Now that I've been in the field for about a year and a half as of writing this Article, I can say confidently that from my "newbies" perspective, there are some issues that need to be addressed if the field is to advance and improve; something I would like to help accomplish. A lot of U.S crime labs are understaffed and underfunded which leads to attrition, and they are in a constant circle and never being able to stay above water. One step forward, two steps back so to speak. Also, in agreement with Dr. Max Houck's assessment on another growing issue in the field, there seems to be an asymmetric power balance when it comes to law enforcement agencies, the prosecution and the forensic service providers who serve them; the forensic service providers being the ones at the bottom of the totem pole. When something goes array (especially on a high profile case) it's, more often than not "the labs fault". (Refer to www.csireality.org for more information on the topic.)

I don't know how to fix all of the issues, and at this point in my career how could I? I'm just making observations. What I DO know is that to fix any issue there needs to be a dialogue started and "uncomfortable" conversations to be had. Because at the end of the day, politics and pay issues aside, we do what we do because something unfortunate happened to someone. They deserve the best, and I want to give it to them. 